\title{
赤スケール生成におよぼす 熱間圧延条件と高圧水デスケーリングの影響
}

\author{
岡田 光*・深川 智機* - 石原 晴彦*・岡本 篤樹* - 吾妻 正敏*2 - 松田 行雄*3
}

Effects of Hot Rolling and Descaling Condition on Red Scale Defects Formation

Hikaru Окаda, Tomoki Fukagawa, Haruhiko Ishihara, Atsuki Окamoto, Masatoshi Azuma and Yukio Matsuda

Synopsis : Red scale defects usually observed in high Si hot rolled strip were reproduced in a laboratory 3 stand tandem mill. The effects of hot rolling and descaling condition on the strip surface color and scale structure were examined.

Irrespective of $\mathrm{Si}$ content in steel, the hot rolled strip surface became red when the scale thickness before rolling was above $20 \mu \mathrm{m}$ and the rolling temperature was below $900^{\circ} \mathrm{C}$. It was found that surface part of the scale (mainly $\mathrm{FeO}$ ) was broken to powder by the hot rolling at the temperature below $900^{\circ} \mathrm{C}$. The red scale of $\mathrm{Fe}_{2} \mathrm{O}_{3}$ was formed by the oxidation of powdered scale during cooling. Thick scale formed during slab soaking was completely removed by hydraulic descaling before rolling in low Si steel, whereas that was not removed in high Si steel. This remained scale caused the red scale defects after rolling and cooling. The application of obtained results to the hot strip mill production of red scaleless strip was discussed.

Key words : scale ; red scale; Si steel ; descaling ; hot rolled product ; rolling ; oxidation.

\section{1. 緒言}

$0.5 \%$ 以上のSiを有する鋼板を熱間圧延すると, 赤スケー ルと呼ばれる帯状のスケール模様が生成する。この赤スケ 一ルを防止するため，加熱温度制御12)，デスケーリング強 化1)等の対策が行われてきたが，その防止手段は完全に確立 されているとはいえない。

赤スケールが発生するのは，加熱中にスケールと地金界 面に生成する低融点酸化物ファイアライト $\left(\mathrm{Fe}_{2} \mathrm{SiO}_{4}\right)$ が通 常の脱スケール条件ではスケールを剝離しにくくするため3) といわれているが, $\mathrm{Fe}_{2} \mathrm{SiO}_{4}$ の生成とスケールの剥離性の関 係，デスケーリング不良と赤スケールの生成の関係等不明 な点が多い。

そこで今回, 連続熱間試験圧延設備4) 用いて赤スケール を実験室的に再現し，その生成条件および防止法の検討を 行ったので報告する。

\section{2. 試験内容}

\section{$2 \cdot 1$ 圧延設備}

Fig. 1 に試験圧延設備を示す。この試験設備は, 電気炉 2 基, エッジャー, 高圧水デスケーラー, 圧延機 3 基, 水冷

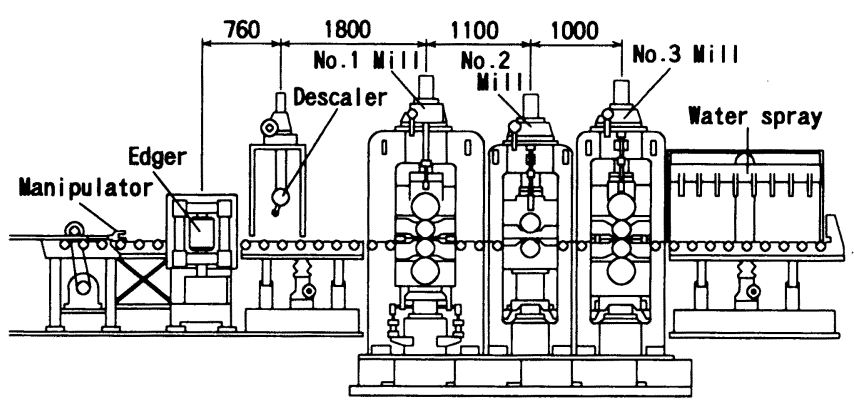

Fig. 1. Experimental apparatus.

ヘッダーから構成されている。

電気炉の最高加熱温度は $1300^{\circ} \mathrm{C} て ゙ ， \mathrm{~N}_{2}, \mathrm{CO}_{2}, \mathrm{H}_{2} \mathrm{O}$ ガス を流すことにより，実機加熱炉と同様の雲囲気で加熱可能 である。また，高圧水デスケーラーの前にロール径 $200 \mathrm{~mm}$ のエッジャーを設置し，実機におけるVSB (Vertical Scale Breaker）を模擬した。エッジャー，高圧水デスケーラー， 圧延機間はマニプレータにより試験片を $0.5 \mathrm{~m} / \mathrm{s} て ゙$ 搬送した。 高圧水デスケーラーは, 実機の仕様とほぼ等しくし, 圧 力 $15 \mathrm{MPa}$, 流量 $1.81 / \mathrm{s}$, スプレー開度 $25^{\circ}$, ノズルの傾斜角 $10^{\circ}$,ノズルと供試材間の垂直距離 $250 \mathrm{~mm}$ とした。

3 基の圧延機の入出側には放射温度計を設置し，圧延前 および圧延中の鋼板表面温度を測定した。圧延機は，入側

平成 6 年 2 月 21 日受付 平成 6 年 9 月 2 日受理（Received on Feb. 21, 1994; Accepted on Sep. 2, 1994)

* 住友金属工業(株) 鉄鋼技術研究所 (Iron \& Steel Research Laboratories, Sumitomo Metal Industries, Ltd., 3 Hikari Kashimamachi Kashima-gun Ibaraki-ken 314)

* 2 住友金属工業(株)和歌山製鉄所 (Wakayama Steel Works, Sumitomo Metal Industries, Ltd.)

*3 住友金属工業(株) 本社 (Head Office, Sumitomo Metal Industries, Ltd.) 
より $4 \mathrm{Hi} ， 2 \mathrm{Hi} ， 4 \mathrm{Hi}$ なっており，それぞれのワークロ ール径は200，220，220mmである。

圧延機出側には, 雾囲気コントロール可能な水冷装置を 設置し, 試験片を大気中または窒素雲囲気中(酸素濃度 0.06 vol\%以下) で水冷した。

\section{$2 \cdot 2$ 供試材料}

Table 1 に供試材料の化学成分を示す。鋼 1 はSiを0.5\% 含有する高張力鋼板 (高Si鋼)，鋼 2 はSi量の低い低炭素鋼 板 (低Si鋼) である。

試験片は，実機連続鋳造されたスラブ $\left(220 \mathrm{~mm}^{\mathrm{t}} \times 1200\right.$ $\mathrm{mm}^{\mathrm{w}}$ )の表皮下 $10 \mathrm{~mm}$ よび中央部 $20 \mathrm{~mm}$ を除いた部分から， 機械加工により $30 \mathrm{~mm}^{\mathrm{t}}, 8 \mathrm{~mm}^{\mathrm{t}} \times 70 \mathrm{~mm}^{\mathrm{w}} \times 200 \mathrm{~mm}^{1}$ に切出し て作成した。その際，試験片のL，C方向は，実機のスラブ と一致する方向とした。

\section{$2 \cdot 3$ 試験方法}

4 種類の熱間圧延試験を行った。模式的にFig. 2 に示す。 (1) 試験 1

高Si鋼，低Si鋼 ( $8 \mathrm{~mm}$ 厚) をそれぞれ同一の材料の試験 片で 2 枚重ねにし, $\mathrm{N}_{2}$ ガス雾囲気中で $820 \sim 1280^{\circ} \mathrm{Cに} 30 \mathrm{~min}$ 加熱した。この加熱方法により，重ね面にはスケールはは とんど生成しない。試験片を炉より取り出し，マニプレー 夕に固定した後，重ねた試験片を分離し酸化放冷を開始し た。 5 ～50s放冷し所定の圧延温度 $(750 ， 800 ， 850 ， 900$, $\left.1000^{\circ} \mathrm{C}\right)$ にた後，1枚は 3 パス圧延，1枚は圧延を行わ ずにただちに水冷した。この圧延を行わなかった試験片の スケール厚を測定し，圧延前のスケール厚とした。それぞ れの圧延機における圧下率は約 $20 \%$ とし，ロール周速は1.67 $\mathrm{m} / \mathrm{s}$ 一定とした。また，圧延後は大気中で水冷した。

( 2 ) 試験 2

Table 1. Chemical composition of specimen (mass\%).

\begin{tabular}{c|c|c|c|c|c|c|c}
\hline Steel & $\mathrm{C}$ & $\mathrm{Si}$ & $\mathrm{Mn}$ & $\mathrm{P}$ & $\mathrm{S}$ & sol. Al & \\
\hline 1 & 0.09 & 0.54 & 1.46 & 0.009 & 0.014 & 0.019 & High Si \\
2 & 0.05 & 0.005 & 0.15 & 0.009 & 0.013 & 0.024 & Low Si \\
\hline
\end{tabular}

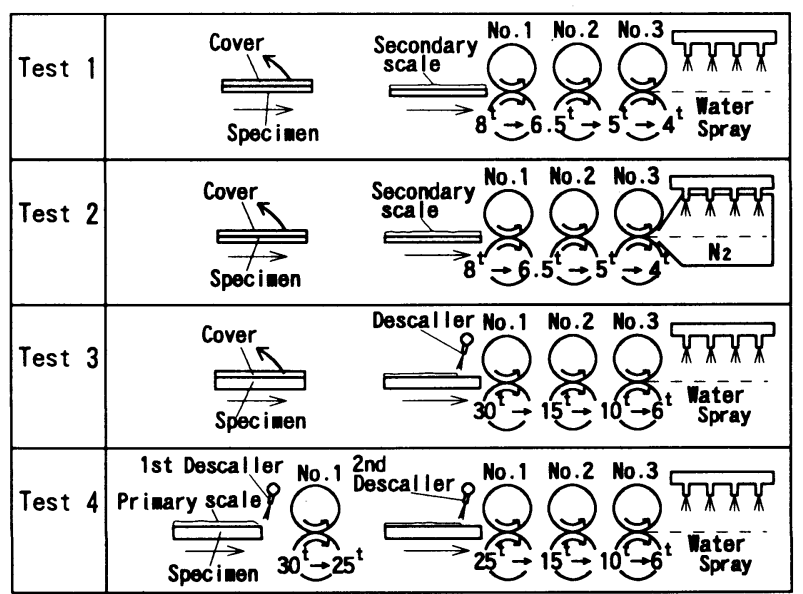

Fig. 2. Schematic illustration of experimental procedures.
低Si鋼（8mm厚）を試験 1 と同様の方法で1000 1280

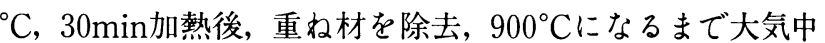
で 7 ～35s放冷し，その後，3 パス圧延を行った。圧延機出 側に $\mathrm{N}_{2}$ 雾囲気としたチャンバーを設置し，その中で常温ま で水冷した。

( 3 ) 試験 3

高Si鋼，低Si鋼 (30mm厚) を試験 1 と同様の方法で 1100 ${ }^{\circ} \mathrm{C}$, 30min加熱後, 重ね材を除去し $\left(\right.$ 約 $\left.1050^{\circ} \mathrm{C}\right)$, 大気中で 40 放冷した後 $\left(\right.$ 約 $\left.970^{\circ} \mathrm{C}\right)$ ，高圧水によるデスケーリング， 約 $900^{\circ} \mathrm{C}$ よ 3 パス圧延，大気中水冷を行った。

( 4 ) 試験 4

実機の熱延をシミュレートするため，試験片を 1 枚ずつ 実機の加熱炉を模した雾囲気 $\left(77.1 \% \mathrm{~N}_{2}+14.3 \% \mathrm{H}_{2} \mathrm{O}+8.6\right.$ $\left.\% \mathrm{CO}_{2}\right)$ 中で $1150 \sim 1300^{\circ} \mathrm{C}, 20 \sim 120 \mathrm{~min}$ 加熱し，1次スケ ールを生成させた後, エッジャーによるスケールブレーキ ング，高圧水デスケーリングを行い，1 次スケールを除去 した。その後 1 パス圧延を行った後, 試験片を 40 s待機させ る事により2 次スケールを生成させ，さらに再度デスケー リングを行い，圧延，大気中水冷を行った。

試験 1 , 試験 2 については, 色彩色差計を用いて鋼板表 面の $\mathrm{L}^{*} \mathrm{a}^{*} \mathrm{~b}^{*}$ 指数 (JIS8729) を測定し，視覚による赤さの変 化とよく対応するクロマティクネス（a*) 值を用いて表面 の色を定量化した。また, 試験後, 走査型電子顕微鏡を用 いてスケール部の断面観察を行った。スケール厚の測定は, 酸洗によりスケールの重量を求め, スケールの密度を $5.7(\mathrm{~g} /$ $\left.\mathrm{cm}^{3}\right)$ として換算した5)。このスケール厚の換算結果は断面 観察の結果と一致する事を確認している。

\section{3. 試験結果}

\section{$3 \cdot 1$ 試験 1}

Fig. 3 に試験片を 2 枚重ねで種々の温度で加熱後, 分離し 約 $900^{\circ} \mathrm{C}$ まで放冷，圧延を行わずにただちに水冷した試験に おける，放冷開始温度とスケール厚の関係を示す。両鋼と

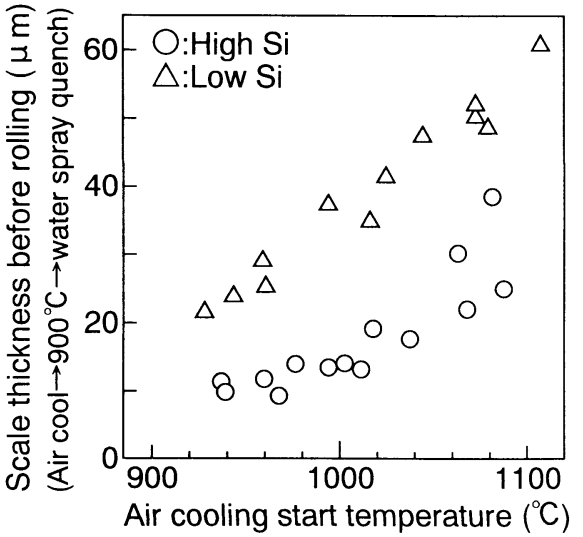

Fig. 3. Effect of air cooling start temperature on scale thickness of steels quenched from 900 ${ }^{\circ} \mathrm{C}$. (Test 1 ) 
もに放冷開始温度が高くなるにつれてスケールは厚くなる。 ただし, 高Si鋼は低Si鋼に比べ同じ放冷開始温度でもスケー ルは薄く, 高Si鋼の方が酸化速度が遅い。また,いずれの場 合でも鋼板表面は黒色を呈していた。この様に，放冷開始 温度を変える事により, 圧延前のスケール厚を変化する事 ができる。

圧延を行った鋼板の表面観察例として, 高 $\mathrm{Si}$ 鋼を $1040^{\circ} \mathrm{C}$

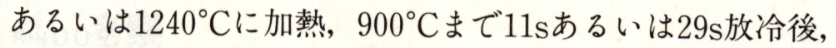
3 パス圧延, 水冷を行った場合の表面写真をFig. 4 に示す。 圧延前の放冷時間が短く, 圧延前のスケールが薄い場合 $(12$ $\mu \mathrm{m}) に$ は鋼板表面は黒色となり，放冷時間が長くスケール が厚い場合 $(30 \mu \mathrm{m})$ は赤色となった。この傾向は低Si鋼で も同様であった。

両鋼における $900^{\circ} \mathrm{C}$ 圧延前スケール厚と圧延水冷後の鋼板 表面のクロマティクネス $\left(\mathrm{a}^{*}\right)$ 值の関係をFig. 5 に示す。圧 延前スケール厚はFig. 3 より求めた。a*值は, 灰色の場合 0 , 赤色が強くなるほど大きな值となる。圧延前のスケールが 厚くなるにつれて $\mathrm{a}$ *值は大きくなり，赤色が強くなった。 また, 四中○は高Si鋼, $\triangle$ は低Si鋼の試験結果だが, 鋼種に よる差は認められなかった。

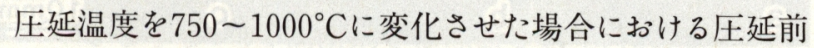
スケール厚と a*值の関係をFig. 6 に示す。Si量によらず圧延 温度が $900^{\circ} \mathrm{C}$ 以下の場合には, 圧延前スケール厚が $20 \mu \mathrm{m}$ 以 上では，a*值は 1 以上となり赤スケールとなるが, 圧延温

\section{Gray scale}

\section{Red scale}

a)

b)

$10 \mathrm{~mm}$

Fig. 4. Surface appearance of high Si steel rolled at $900^{\circ} \mathrm{C}$ and quenched. (Test 1 )

(a) Heat : $1040^{\circ} \mathrm{C} \rightarrow$ air cool : $11 \mathrm{~s} \rightarrow$ hot roll

(b) Heat : $1240^{\circ} \mathrm{C} \rightarrow$ air cool $: 29 \mathrm{~s} \rightarrow$ hot roll

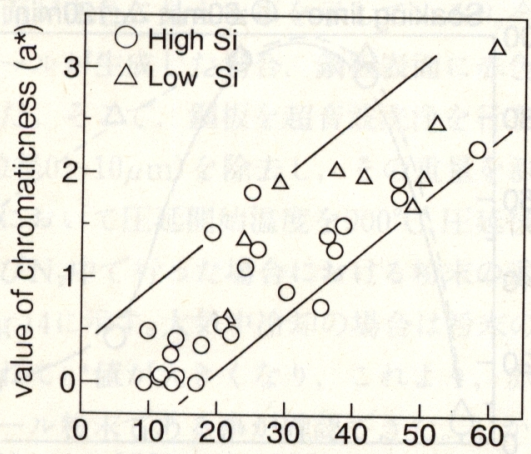

Scale thickness before rolling $(\mu \mathrm{m})$

Fig. 5. Effect of scale thickness before rolling on value of chromaticness $\left(\mathrm{a}^{*}\right)$ of steel rolled at $900^{\circ} \mathrm{C}$ and quenched. (Test 1 )

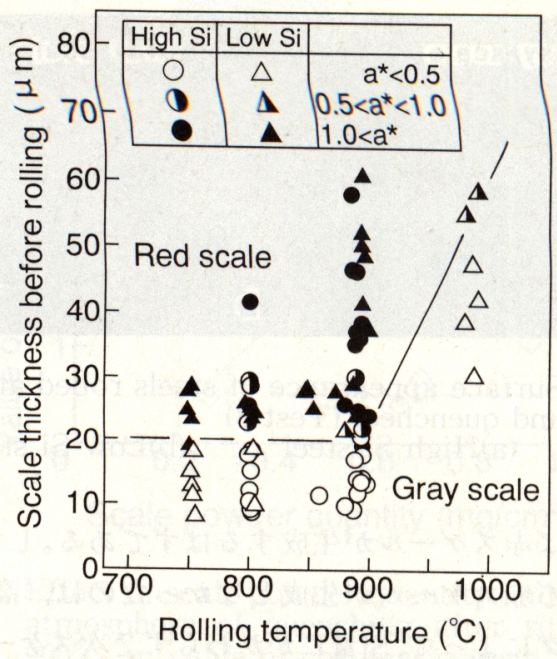

Fig. 6. Effects of scale thickness before rolling and rolling temperature on value of chromaticness $\left(\mathrm{a}^{*}\right)$ of low $\mathrm{Si}(0.005 \%)$ steel and high $\mathrm{Si}(0$. $5 \%$ ) steel. (Test 1)

度が $1000^{\circ} \mathrm{C}$ 場合は, スケール厚が $50 \mu \mathrm{m} て ゙ も 0.5$ 以下の值 となり赤スケールは生成しなかった。この様に圧延前スケ ール厚と圧延温度が赤スケール発生上重要な事がわかった。

\section{$3 \cdot 2$ 試験 2}

圧延後の酸化の影響を調べるため, 低Si鋼を 3 パス圧延後, 冷却雲囲気を $\mathrm{N}_{2}$ とした試験を行った。

この場合の圧延前スケール厚と $\mathrm{a}^{*}$ との関係をFig. 7 に示す。 圧延後の鋼板を $\mathrm{N}_{2}$ 雲囲気中で冷却すると, 圧延前スケール 厚にかかわらず鋼板は赤色にならない。 $\mathrm{a}$ *值も大気中と比 べ小さく，スケール厚によらずほぼ一定の值となった。

\section{$3 \cdot 3$ 試験 3}

2 次スケールを大気中 40 s放冷して生成させた後, 高圧デ スケーリングを行い, その後約 $900^{\circ} \mathrm{C} て ゙$ 圧延, 水冷した鋼板 の表面写真をFig. 8 に示す。高Si鋼, 低Si鋼共に黒色の表面 となり，赤スケールは生成しなかった。

この場合, 高 $\mathrm{Si}$ 鋼では $40 \mu \mathrm{m}$ 厚の, 低Si鋼では60 $\mu \mathrm{m}$ 厚の スケールがデスケーリング前には生成しており, 試験 1 の 結果より，デスケーリングによってスケールが除去できて

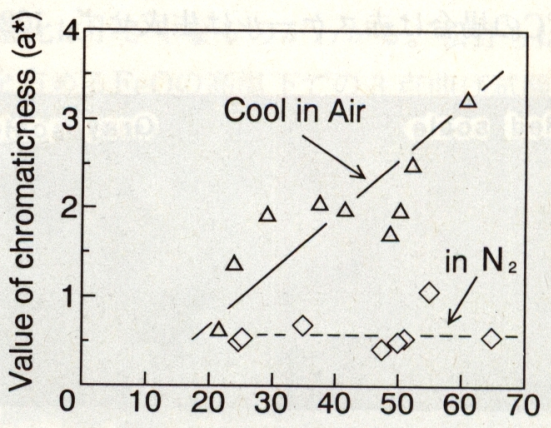

Scale thickness before rolling $(\mu \mathrm{m})$

Fig. 7. Effects of scale thickness before rolling and cooling atmosphere of quenching after rolling on value of chromaticness $\left(\mathrm{a}^{*}\right)$. (Test 1,2 ) 


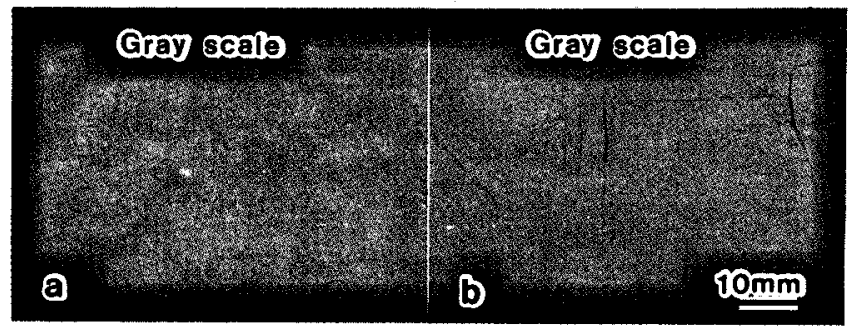

Fig. 8. Surface appearance of steels rolled at $900^{\circ} \mathrm{C}$ and quenched. (Test 3)
(a)High Si steel
(b)Low Si steel

いなければ赤スケールが生成するはずである。したがって， この試験で赤スケールが生成しなかったのは，高圧水デス ケーリングによって, Si量にかかわらず 2 次スケールが完全 に剝離したためと考えられる。

\section{$3 \cdot 4$ 試験 4}

次に, 加熱炉内で生成するスケールの影響を調べるため, 高Si鋼，低Si鋼を実機を模した雾囲気中で $1220^{\circ} \mathrm{C}, 2 \mathrm{~h}$ 加熱 した。試験片を炉より取り出し，スケールブレーキング, 1 次デスケーリング, 1 パス压延, 2 次デスケーリング, 3 パス圧延, 水冷を行った。この試験では, 1 パス圧延時 の鋼板温度が約 $1050^{\circ} \mathrm{C}, 3$ パス圧延時の鋼板温度が約 $900^{\circ} \mathrm{C}$ であった。

圧延後の試験片表面写真をFig. 9 に示す。低Si鋼では, 試 験片表面が黒色を呈するのに対し, 高Si鋼では赤スケールが 生成した。

また，この試験において，1次デスケーリング後および 2 次デスケーリング後のスケール断面写真をFig.10に示す。 低Si鋼では,どちらもほとんどスケール残りは無いが, 高Si

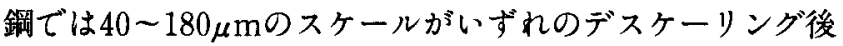
にも残っていた。

高Si鋼において, $1220^{\circ} \mathrm{C}, 2 \mathrm{~h}$ 加熱の場合, 鋼板全面に赤 スケールが生成したが，加熱条件を変えると，赤スケール の状態が変化した。Fig.11に加熱時間を20，40，60minに変 えた場合の, Fig.12に加熱温度を $1150,1220,1300^{\circ} \mathrm{Cに}$ 変え た場合の圧延，水冷後の鋼板表面を示す。加熱時間が短い 場合，鋼板表面は赤色が薄くむら状となる。また，加熱温 度が $1150^{\circ} \mathrm{C}$ 場合は赤スケールは生成せず， $1220^{\circ} \mathrm{C} て ゙$ 全面

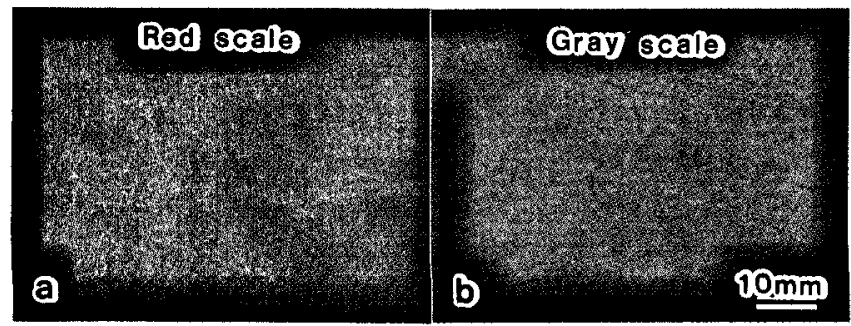

Fig. 9. Surface appearance of steels soaked at 1220 ${ }^{\circ} \mathrm{C}$, 1st descaled, rolled, air cooled for $40 \mathrm{~s}$, 2nd descaled, rolled at $900^{\circ} \mathrm{C}$ and then quenched. (Test 4)
(a)High Si steel
(b)Low Si steel

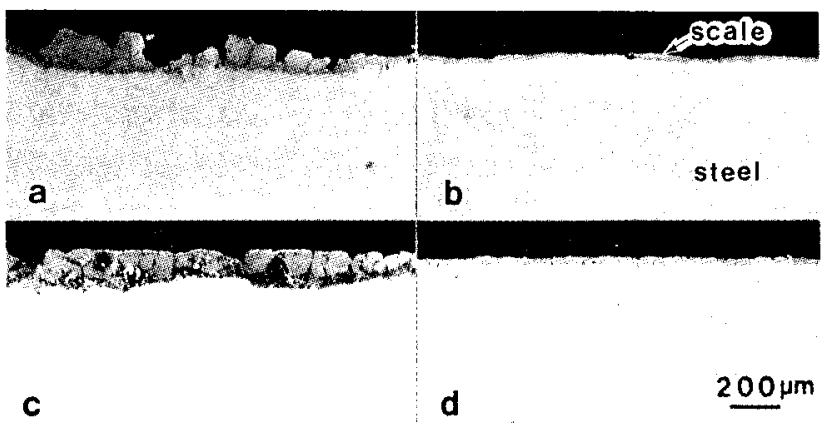

Fig. 10. Cross section SEM micrographs of steels after descaling. (Test 4)

(a)High Si steel after 1st descaling

(b)Low Si steel after 1st descaling

(c)High Si steel after 2nd descaling

(d)Low Si steel after 2nd descaling

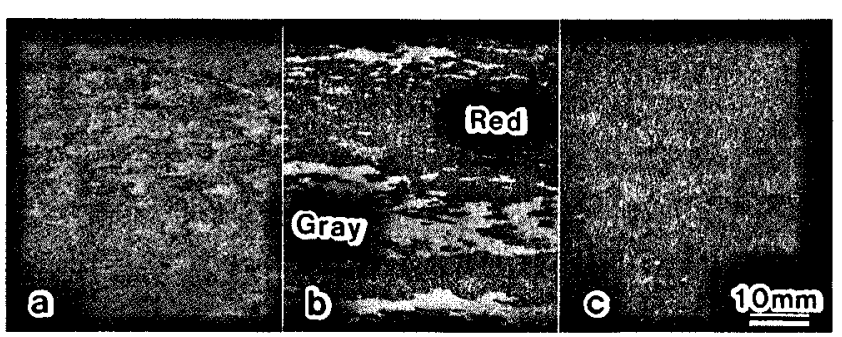

Fig. 11. Surface appearance of high Si steel soaked at $1220^{\circ} \mathrm{C}$ for (a) $20 \mathrm{~min}$, (b) $40 \mathrm{~min}$ or (c) $60 \mathrm{~min}$, descaled and rolled. (Test 4)

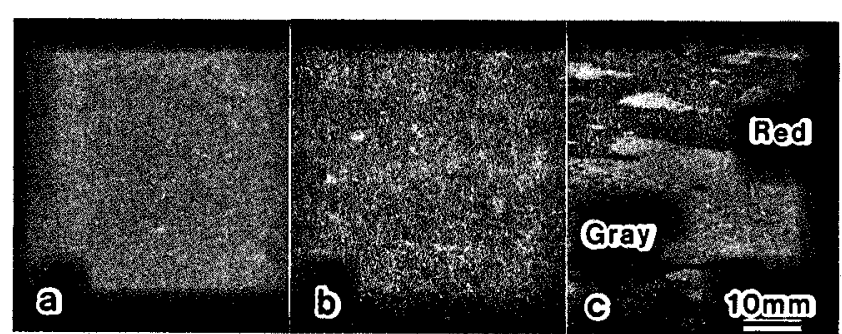

Fig. 12. Surface appearance of high Si steel soaked at (a) $1150^{\circ} \mathrm{C}$, (b) $1220^{\circ} \mathrm{C}$ or (c) $1300^{\circ} \mathrm{C}$ for $2 \mathrm{~h}$, descaled and rolled. (Test 4)

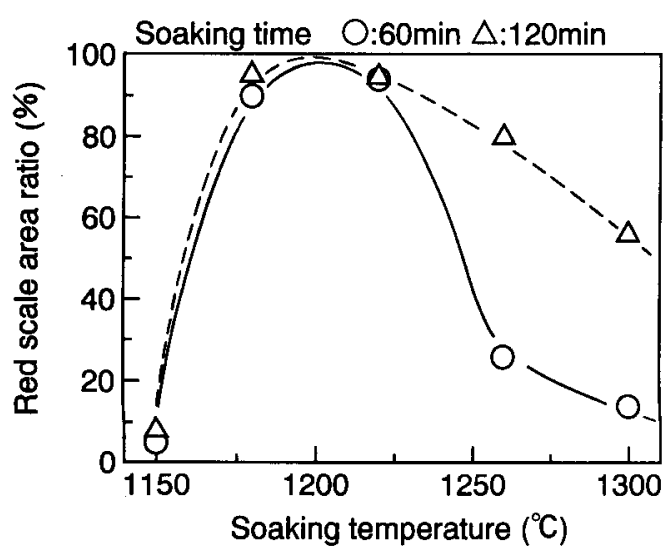

Fig. 13. Effects of soaking temperature and time on red scale area ratio of high Si steel. (Test 4) 
に， $1300^{\circ} \mathrm{C} て ゙ は$ 部分的に生成した。

Fig.13に加熱時間, 加熱温度を変えた時の赤スケール面積

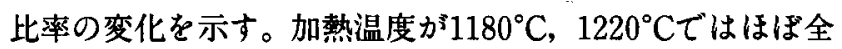
面に赤スケールが生成し，それ以上温度が高くなると赤ス ケールの比率が下がってくるが，加熱時間が短い方が高温 での赤スケールの比率がより小さくなった。

\section{4. 考察}

赤スケールの生成について試駼結果をまとめると次のよ うになる。

1) Si量によらずスケール厚が $20 \mu \mathrm{m}$ 以上でかつ $900^{\circ} \mathrm{C}$ 以下で 圧延すると冷却後に赤スケールが発生する。

2 ) 圧延後 $\mathrm{N}_{2}$ 中で冷却し，酸化を抑制すると赤スケールにな らない。

3 ）Si量によらず短時間放冷 (40s)で形成させた,いわゆる 2 次スケール $(40 \sim 60 \mu \mathrm{m})$ 仿高圧水で除去され, 圧延, 冷却後 には赤スケールにならない。

4) 加熱炉で長時間酸化され形成された厚い1次スケール $(0.5 \sim 3.0 \mathrm{~mm})$ は, 低Si鋼では高圧水で除去され圧延後赤ス ケールとならないが,高Si鋼では除去されず, 冷却後赤スケ ールとなる。

5 )この高Si鋼での赤スケールは加熱時間が長い方が生成し やすいが，加熱温度は $1260^{\circ} \mathrm{C}$ 以上になるとかえって生成し

にくく赤スケール面積率は低下する。

以上の結果は次のように整理できる。

a) $\mathrm{Si}$ 量にかかからず，熱間圧延時のスケール厚と圧延温度 と冷却時の酸化条件により赤スケール﨡生成寸る。

b) 高Si鋼特有の現象として, 高温長時間の酸化で形成され たスケールは高圧水では除去されず, 压延, 大気水冷後赤 スケールとなる。ただし，加熱蕰度 $1260^{\circ} \mathrm{C}$ 以上では赤スケ 一ルが減少する。以下これを考察する。

\section{$4 \cdot 1$ スケール粉末と赤スケールの関係}

浅井らは酸化スケールの色とスケール粉末の関係を調查 $L$, 粒径 $2 \mu \mathrm{m}$ 以下のへマタイト $\left(\alpha \mathrm{Fe}_{2} \mathrm{O}_{3}\right)$ 粉末が存在する と鋼板表面が赤色に見える事を示している61。今回の試験で も赤スケールが生成した場合, 鋼板表面に赤色の粉末が生 成していた。そこで，鋼板を超音波洗浄を行う事によりこ の粉末(粒径 $0 \sim 10 \mu \mathrm{m})$ を除去し，その重量を測定した。

低Si銅において圧延開始温度を $900^{\circ} \mathrm{C}$, 圧延後の冷却を大 気中およびN ${ }_{2}$ 中で行った場合における粉末の重量と $\mathrm{a}$ *值の 関係をFig.14に示す。大気中冷却の場合蛙粉末の重量が多く なるにつれて $\mathrm{a}^{*}$ 值が大きくなりこれより，赤色の原因は このスケール粉末である事が磼認できた。しかし， $\mathrm{N}_{2}$ 中冷 却の場合には粉末の重量が增加しても

またここのスケール粉末をX線回折により同定すると大気 中冷却の場合はへマタイト $\left(\alpha \mathrm{Fe}_{2} \mathrm{O}_{3}\right)$ であったのに対し, $\mathrm{N}_{2}$ 中冷却の場合は, ウスタイト $(\mathrm{FeO})$, マグネタイト $\left(\mathrm{Fe}_{3} \mathrm{O}_{4}\right)$

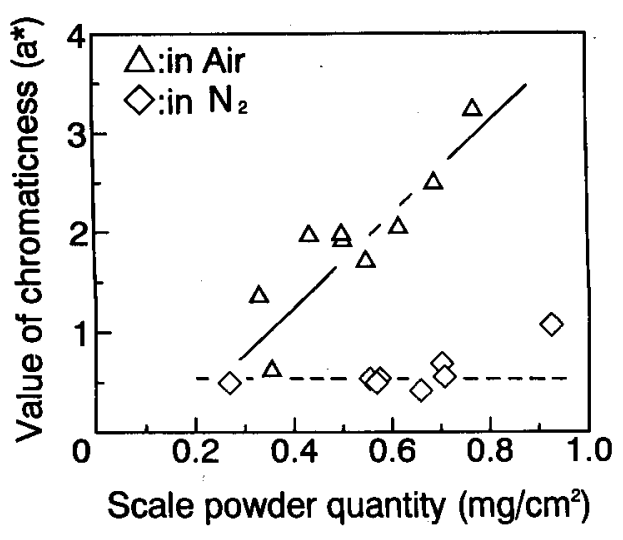

Fig. 14. Effect of scale powder quantity and cooling atmosphere of quenching after rolling at $900^{\circ} \mathrm{C}$ on value of chromaticness $\left(\mathrm{a}^{*}\right)$.

(Test 1,2)

のみであり,へマタイト $\left(\alpha \mathrm{Fe}_{2} \mathrm{O}_{3}\right)$ ははとんど検出されなか つた。

従来, 高温下で生成するスケールは $\mathrm{Fe} / \mathrm{FeO} / \mathrm{Fe}_{3} \mathrm{O}_{4} / \alpha \mathrm{Fe}_{2}$

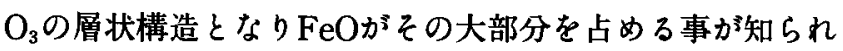
ている。スケールが生成した状態で压延を行うと，その一 部が圧延によって破壊され，粉状のFeOが生成し， $\mathrm{N}_{2}$ 中で

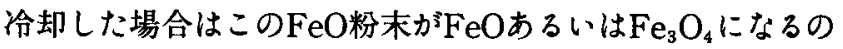
に対し, 大気中冷却の場合には, 酸化が進み $\alpha \mathrm{Fe}_{2} \mathrm{O}_{3}$ となり 赤色を呈すると考えられる。

また，スケール粉末の重量は压延前スケール厚に比例し ていた。Fig. 5 で圧延前スケールが厚くなるはに゙赤色が強く なるのは, $\alpha \mathrm{Fe}_{2} \mathrm{O}_{3}$ 粉末の增加のためと考えられる。

\section{$4 \cdot 2$ 圧延温度の影整}

約 $30 \mu \mathrm{m}$ のスケールを生成させた後, $750^{\circ} \mathrm{C}$ るいは 1000 ${ }^{\circ} \mathrm{C} て ゙ 3$ パス圧延を行った時のスケール断面写真をFig.15に示

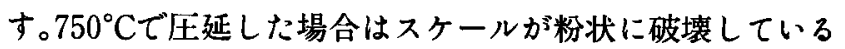
のに対し， $1000^{\circ} \mathrm{C}$ 場合は粉状破壊が認められない。

これらの鋼板のスケール総重量 $と$, 超音波洗浄により求 めたスケール粉末の重量の比を求めた。 3 パス圧延温度と 圧延後のスケール重量中に占めるスケール粉末の重量比の 関係をFig.16に示す。圧延温度が高くなるにつれてスケール 粉末の重量比は小さくなるのがわかる。松野らは, スケー ルの大半を占める $\mathrm{FeO}$ 高温下での 3 点曲げ試験を行い, 高 温になるほど降伏強度が下がる事を示している7゙これらか ら高温で圧延した場合にはスケールが变形しやすく，粉状

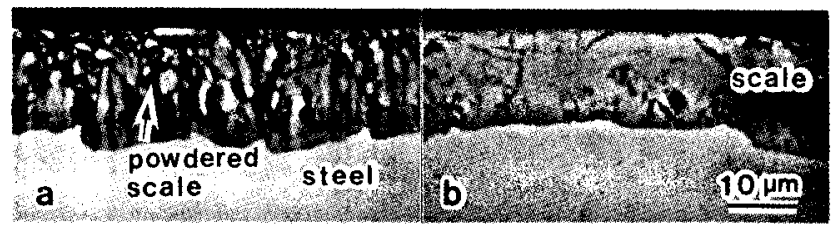

Fig. 15. Cross section SEM micrographs of low $\mathrm{Si}$ steel rolled at $(\mathrm{a}) 750^{\circ} \mathrm{C}$ or $(\mathrm{b}) 1000^{\circ} \mathrm{C}$. (Test 1) 


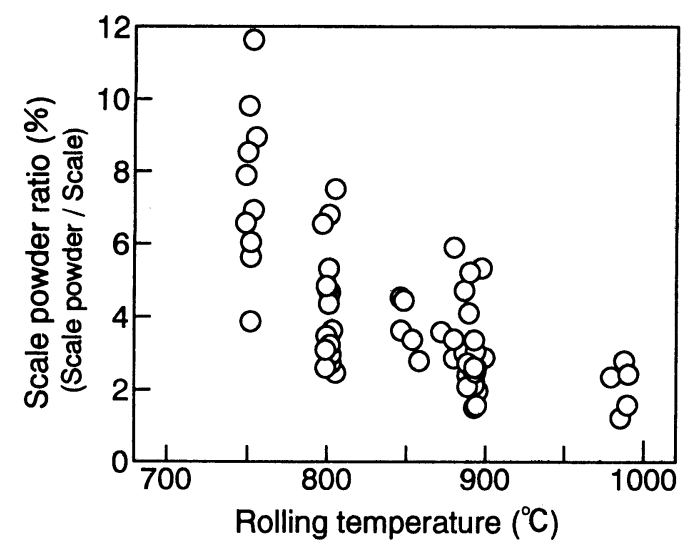

Fig. 16. Effect of rolling temperature on the ratio of scale powder to total scale weight.

に破壊しにくいと考えられる。Fig. $6 て ゙, 1000^{\circ} \mathrm{C}$ 圧延した場 合スケールが厚くても赤スケールにならなかったのはこの 為であろう。

一方, 圧延温度が低くなると圧延時にスケールが粉末化 しやすくなり，圧延前のスケールが薄くても粉末量は多く なる。しかし, 低温のため $\mathrm{FeO} \rightarrow \alpha \mathrm{Fe}_{2} \mathrm{O}_{3}$ の酸化が進みにく くなり，そのため $900^{\circ} \mathrm{C}$ 以下の圧延ではスケール厚が $20 \mu \mathrm{m}$ 以上の場合のみ赤スケールが生成したと考えられる。

\section{$4 \cdot 3$ 高Si鋼における赤スケールの生成}

試験 3 で示した様に，鋼板を 40 秒間放冷し生成させたい わゆる 2 次スケールは, Si量によらず高圧水デスケーリング によって容易に剝離し, 䞑ケールとならない。しかし, 高Si鋼を加熱炉で長時間酸化した 1 次スケールは,デスケー リング後でも 40〜 $180 \mu \mathrm{m}$ のスケール $(\mathrm{FeO}$ 主体)が取れ残り, スケールが付いたまま圧延されるので，押し込みになると 同時に圧延中にスケールが破壊し粉末が生成して赤スケー ルとなる。長時間加熱した高Si鋼では，スケール/鋼界面に 入りくんだファイアライト $\left(\mathrm{Fe}_{2} \mathrm{SiO}_{4}\right)$ が生成しており,これ がスケールの剝離性を悪化させている2)

加熱温度が $1220^{\circ} \mathrm{Cを}$ 越えると赤スケール面積率が減少し, Fig.12(c)で示したように銅板表面は赤黑のむらとなる。実 機でよく観察される赤スケール模様はこの状態に相当して いると思われる。このスケールむらが生じるのは, デスケ ーリングが $\mathrm{Fe}_{2} \mathrm{SiO}_{4}$ の融点 $\left(1173^{\circ} \mathrm{C}\right)$ 以上で行われるのでスケ 一ルが部分的に剝離するためと思われるが，この詳細につ いては別報 ${ }^{8)}$ に検討する。

\section{$4 \cdot 4$ 実機での赤スケール防止法}

本実験結果を実生産のホットストリップミルに適用する と, 赤スケール疵防止は, $900^{\circ} \mathrm{C}$ 以下の圧延, すなわち仕上 圧延機でのスケールの粉化抑制が重要で，具体的には，仕 上圧延機前での完全なデスケーリングとデスケーリング後
圧延までの酸化抑制が必要といえる。

特に高Si鋼では, スラブの加熱条件の調整による $\mathrm{Fe}_{2} \mathrm{SiO}_{4}$ の抑制, デスケーリングの強化, あるいはデスケーリング 時の温度条件などによるスケールの除去がより重要となる。 圧延後の冷却条件も粉化したスケールの酸化防止の観点 で重要だが，制御は難しいと思われる。

\section{5. 結言}

Siを0.5\%以上含有する鋼を熱間圧延した際に発生する赤 スケール疵を実験室的に再現し，その生成条件および防止 法について検討した。

(1) 高Si鋼 $(0.54 \% \mathrm{Si})$, 低Si鋼 $(0.005 \% \mathrm{Si})$ にかかわらず, 圧延前のスケール厚が $20 \mu \mathrm{m}$ 以上で $900^{\circ} \mathrm{C}$ 以下で連続圧延, 水スプレ一冷却を行うと, 赤スケールが生成する。

(2) 赤スケールの原因は赤い粉状の $\alpha \mathrm{Fe}_{2} \mathrm{O}_{3}$ (ヘマタイト) であり,これは, $900^{\circ} \mathrm{C}$ 以下の圧延によって粉状に破壊され た $\mathrm{FeO} よ ひ ゙ \mathrm{Fe}_{3} \mathrm{O}_{4}$ が圧延後の冷却時に酸化が進み $\alpha \mathrm{Fe}_{2} \mathrm{O}_{3}$ となる事によって生じる。

( 3 ) 圧延中に短時間で生成した2 次スケールはSi量にかか わらず高圧水デスケーリングによって容易に除去されるた め, 圧延前のスケール厚は薄く, 赤スケールにならない。

( 4 ) 高Si鋼を実機加熱炉を模した雲囲気で長時間加熱す ると, $\mathrm{Fe}_{2} \mathrm{SiO}_{4}$ の生成により, 高圧水デスケーリングで40〜180 $\mu \mathrm{m}$ のスケールが取れ残り,これが付いたまま圧延されるた め赤スケールが生成する。

( 5 ) 高Si鋼における赤スケールの生成は, 加熱条件に大き な影響を受け, 加熱温度が1180〜 $1220^{\circ} \mathrm{Cで} \mathrm{1} \mathrm{〜} 2$ h加熱した 場合全面が赤色となるが， $1260^{\circ} \mathrm{C}$ 以上の加熱では赤色のむ らが生成した。

( 6 ) 以上の様に, 実生産では鋼中のSi量, スラブの加熱温 度, デスケーリング条件 (スケール厚), 圧延温度, 圧延後 の冷却条件の制御が赤スケール防止に必要な事が明らかに なった。

\section{文献}

1 ) 石井吉秀, 小土井章夫, 若松郁夫：材料とプロセス，6 (1993), p. 1340

2 ) 沖田美幸, 永井秋男, 品川岩美, 堀之内耕一：材料とプロセス, 2 (1989), p.1509

3 ) 小野田克己, 岡部 央, 能美亮一, 長谷 登 : 住友金属, 20 (1968) $1, \mathrm{p} .23$

4 ）佐々木保, 新城昭夫, 国重和俊, 沖田美幸, 江袋忠男 : 住友金属, 44 (1992) 3, p.23

5 ）松野二三朗：鉄 と鋼，65 (1979), p.599

6 ) 浅井達也, 中村峻之, 井上 毅：材料とプロセス, 6 (1993), p.357

7 ）松野二三朗, 錦田俊一：鉄 と鋼，71 (1985), S1282

8 ) T.Fukagawa, H.Okada and Y.Maehara : ISIJ Int. 投稿中 